\title{
Bangladesh's dillema between big brothers India and China
}

\section{El dilema de Bangladesh entre los hermanos mayores India y China}

DOI: $10.46932 / \mathrm{sfjdv2n3-050}$

Received in: May 1st, 2021

Accepted in: Jun 30th, 2021

\author{
Satyaki Aditya \\ Highest Academic Background: MPhil Scholar in International Relations \\ Institution: Jadavpur University \\ Address: Department of International Relations, Jadavpur University, Kolkata-700032 \\ E-mail: satyakiaditya022@gmail.com
}

\begin{abstract}
Bangladesh is a small state in South Asia, but its pivotal geostrategic location on the contested Indian Ocean Region (IOR) and being one of the world's fastest growing economies with 160 million population helps overshadow the small territorial size of the country. Soon after independence, in 1975 with Chinese recognition, the tug-of-war for hegemonic influence in Bangladesh began between India \& China. This paper wants to test the conventional wisdom whether 'Great power rivalries make smaller nations vulnerable.' The paper also endeavours to predict the future relationship between the two giants in Asia amid all tensions regarding their association in regional forums like ASEAN, BIMSTEC and initiatives like BRI. The research wants to identify the strategic options in foreign policy for Dhaka and whether they have been successful in turning the neighbour's rivalry into billions of dollars in investment.
\end{abstract}

Keywords: South Asia, Indian Ocean Region, hegemonic tug-of-war, great powers, regional forums, foreign policy

\section{RESUMEN}

Bangladesh es un pequeño estado del sur de Asia, pero su ubicación geoestratégica fundamental en la disputada región del Océano Índico (IOR) y el hecho de ser una de las economías de más rápido crecimiento del mundo, con 160 millones de habitantes, ayudan a eclipsar el pequeño tamaño territorial del país. Poco después de la independencia, en 1975, con el reconocimiento de China, comenzó el tira y afloja por la influencia hegemónica en Bangladesh entre India y China. Este documento quiere poner a prueba la sabiduría convencional de que "las rivalidades de las grandes potencias hacen vulnerables a las naciones más pequeñas". El documento también intenta predecir la futura relación entre los dos gigantes de Asia en medio de todas las tensiones relativas a su asociación en foros regionales como la ASEAN, el BIMSTEC e iniciativas como la BRI. La investigación quiere identificar las opciones estratégicas en política exterior para Dhaka y si han tenido éxito en convertir la rivalidad del vecino en miles de millones de dólares en inversiones.

Palabras clave: Asia Meridional, Región del Océano Índico, tira y afloja hegemónico, grandes potencias, foros regionales, política exterior. 


\section{INTRODUCTION}

The tug-of-war between India and China for influence in Bangladesh dates back to $31^{\text {st }}$ August 1975, when China became one of the last countries to recognise Bangladesh as an independent nation. India on the other hand was so called 'the liberator' in Bangladesh's War of Independence: intervention of Indian troops sent by Mrs. Indira Gandhi brought an end to the nine long month's campaign of genocide and ethnic cleansing within nine days. Bangladesh was thus born with direct military aid from India and its ruling party, the Awami League, had close ties with New Delhi. The environment of friendship, though started changing with the assassination of the leader Sheikh Mujibur Rahman on August 1975 by junior army officers and the party lost its power in the helm. The new regime that came to power began negotiations with China to get rid of India's overwhelming influence. Ziaur Rahman, the army chief of staff and later president, initiated the programme. He formed a new party, Bangladesh National Party (BNP) which is now the major opposition in the country with Prime Minister Sheikh Hasina of Awami League in power. The post-1975 era was the golden time for China in Bangladesh in terms of civil and military cooperation, also in the arena of foreign policy. Domestic political opinion in Bangladesh is polarized between these two neighbours since then.

\section{DECODING SINO-BANGLADESH RELATIONSHIP: FORMERLY ADVERSARIAL RELATIONSHIP TO AN ENDURING STRATEGIC PARTNERSHIP}

The relationship between Bangladesh and China has undergone a sea change over the years. During the liberation war of 1971 China supported Pakistan and even in the post-independence scenario China had vetoed the entry of Bangladesh into the United Nations. Since then a significant transformation makes Beijing an all-weather trusted ally of Dhaka. In 1977, military dictator Ziaur Rahman visited China as the first head of the state to do so. This major impetus has been maintained since and we get to see the consistency with the successive governments after democracy was re-established in the south Asian state in 1991. Democratically elected leaders have been visiting China regularly with the current Prime Minister Sheikh Hasina visiting China recently in 2014 and July 2019. The two countries share defence, economic, political and people-to-people ties.

DEFENCE - China is the largest and most important provider of military hardware and training to Bangladeshi armed forces. Armed forces in Bangladesh mostly use Chinese built weaponry and Bangladesh has built its only weapon manufacturing factory in Joydebpur, Dhaka. It is worth mentioning that after liberation, Dhaka had inducted the repatriated Pakistani officers into the army who were familiar with Chinese arms, because of this familiarity Bangladesh army started sourcing arms from China. China is the only country with whom Bangladesh has signed a Defence Cooperation Agreement during Khalida 
Zia's visit to China in 2002. According to the then foreign minister, "training of the troops was its main focus". ${ }^{1}$ In March 2006, China donated police equipment's as a part of cooperative efforts between the Ministry of Home Affairs of Bangladesh and the Public Security Ministry of China. ${ }^{2}$ This dependence on Chinese arms had made the armed forces of Bangladesh a strong supporter of defence cooperation. In the same year Bangladesh had received 65 artillery guns, 114 missiles and related systems from China. Most of the tanks (T-59, T-62, T- 69, T-79), a large number of armoured personal carriers (APC) used by Bangladeshi armed forces are of Chinese origin. Bangladeshi Navy has also received the 053-H1 Jianghu 1 class frigates with 4 x HY2 missiles, Huang Feng class missile boats, Type 024 missile boats, Huchuhan and P class torpedo boats, Hainan class sub chasers, Shanghai class gun boats and Yuchin class LCU's. The BNS Khalid Bin Walid has been equipped with HQ-7 SAM from China. In 2008 BNS Osman successfully test fired a C-802 ASM in the presence of Chinese Defence Attaché. ${ }^{3}$ China begun supplying fighter aircrafts to Bangladeshi air force in 1977, and over the years has supplied F-7, Q-5 fighter aircrafts and PT-6 Trainers. Every year around seventy personnel of Bangladeshi armed forces are sent to China for training. The two countries are further planning to expand their cooperation further to complement their respective contributions in the UN Peacekeeping Missions. ${ }^{4}$ It is worth noting that since the 1990s, the top three recipients of Chinese arms exports have been Pakistan, Burma, and Bangladesh; $90 \%$ of Chinese arms exports target India's neighbours in South Asia.

ECONOMIC RELATIONS - Bilateral trade between Bangladesh and China trebled to nearly $\$ 12$ billion in the past decade thanks to the soaring imports by industrialists and businesses. Trade between the two nations, which was $\$ 3.51$ billion in $2008-09$, rose to $\$ 12.38$ billion in $2017-18$. And in the first nine months of the just concluded fiscal year trade stood at about $\$ 11$ billion, with the balance heavily tilted towards China, according to data compiled by Federation of Bangladesh Chambers of Commerce and Industry (FBCCI). Import from China has been increasing gradually while shipment to the world's second biggest economy have been hovering below $\$ 1$ billion for the last several years. Analysts and entrepreneurs says that Bangladesh gets duty-free access for nearly 5,000 items under the Asia Pacific Trade Agreement (APTA) and due to request from Dhaka but businesses cannot take full advantage of the opportunity owing to the country's small export basket. ${ }^{5}$

\footnotetext{
${ }^{1}$ Nazmul Ashraf, "Dhaka-Beijing deal no threat to India”, Gulf news, 29 December 2002

2 “China donates policy equipment to Bangladesh", People's Daily, 23 ${ }^{\text {rd }}$ March 2006

3 “China Bangladesh Relations and Potentials for Regional Tensions", URL: http:// www.jamestown.org/chinabrief

4 "Bilateral Political Relations", Embassy of People Republic of Bangladesh, available at http://www.bangladeshembassy.com.cn/em

${ }^{5}$ Zhang Lei, Chief of Political Section of the Embassy of PRC to Bangladesh, stated the figure in "Presentation of Chinese Political and Economic Development of Bangladesh", available at www.biiss.org/lei.pdf
} 
"We have nothing but garments while they produce almost everything. They have little to buy from us," said Anwar-ul-Alam Chowdhury, president of the Bangladesh Chamber of Industries. ${ }^{6}$ It would be very difficult to increase exports to China unless Bangladesh's exportable products are expanded, said Chowdhury, also a former president of the Bangladesh Garment Manufacturers and Exporters Association. Data compiled by the FBCCI showed that garment accounted for 56 percent of the total exports of $\$ 695$ million to China in fiscal 2017-18.Jute and jute goods accounted for 19 percent of total shipments that year, followed by leather and leather goods at 9 percent. Exporters also shipped items namely frozen foods, footwear, home textile, optical photographic instruments, plastic and plastic articles, furniture and engineering products as well. Nearly 50 percent of the products imported from China are meant for export-oriented industries to make products for the export market and the rest come for domestic consumption, adding that trade imbalance between two nations is rising because of a spiral in capital machinery imports. China tops the list of Bangladesh's import whereas ranks $13^{\text {th }}$ in terms of exports (2016 data) and thus shows how imbalanced is the trade in favour of Beijing.

China has provided considerable monetary assistance on easy conditions on building infrastructure in Bangladesh. It has helped construct at least six "China-Bangladesh Friendship" bridges, Boropukuria power plant among others. The Bangabandhu International Convention Centre build in Sher-e-Bangla Nagar was a gift to Dhaka from Chinese people. Prime Minister Sheikh Hasina's official visit to China last July seemingly succeeded in bolstering ties between the countries. During the trip, both sides inked a host of agreements, including two deals to provide loans to the Bangladeshi power sector, worth \$1.7 billion ( $€ 1.52$ billion). The countries also expressed interest in accelerating the work related to the Bangladesh-China-India-Myanmar Economic Corridor (BCIM EC) project, an initiative aimed at expanding the economic ties of the four countries that together are home to nearly 3 billion people.

Bangladesh and China turned their relationship into a strategic partnership in 2016, and, in recent years, Chinese investment in the South Asian country has risen rapidly. As part of Chinese President Xi Jinping's Belt and Road Initiative (BRI), Beijing and Dhaka signed deals worth $\$ 21.5$ billion covering a raft of power and infrastructure projects. To date, pledged BRI-related investment in Bangladesh stands at around $\$ 38$ billion, estimates Standard Chartered, a British bank.

China has pumped more money into Bangladesh than any other country over the past couple of years. Bangladesh saw a record inflow of foreign direct investment (FDI) in 2018, with the country attracting some $\$ 3.6$ billion of FDI, $68 \%$ higher than in the preceding year, according to a report by the

\footnotetext{
${ }^{6}$ Interview by Zobaer Ahmed, available at http://p.dw.com/p/3Lvzh
} 
United Nations Conference on Trade and Development (UNCTAD). China alone accounts for almost a third of this investment, worth over $\$ 1$ billion. $^{7}$

Bangladesh now increasingly relies on Chinese money to achieve its ambitious target of producing 24,000 megawatts of power by 2022, up from 17,000 megawatts now. The Padma Bridge, a major roadrail project across the Padma River, is being built by the China Major Bridge Engineering Company. And China's Exim Bank is providing \$3 billion for the construction of the rail link accompanying the bridge. Bangladesh has announced an ambitious plan to set up 100 special economic zones by 2030. Many Chinese companies appear interested in investing in these zones. Zhejiang Jindun Pressure Vessel Co Ltd., for instance, has offered to invest $\$ 5$ billion in one such site near Chittagong. ${ }^{8}$

\section{INDIA AND BANGLADESH - A BOND TRANSCENDING STRATEGIC PARTNERSHIP}

The people of India and Bangladesh share close and multi-faceted cultural, religious, linguistic ties because Bangladesh was a part of India under British rule and political and religious reasons for its divisions can undermine this fact. Given the geographical proximity as neighbours the two countries have a common destiny and it is no denying that Bangladesh will remain India's most strategic partner in South Asia and is crucial for stability in the north-eastern region and as a bridge to South East Asia. It is thus lynchpin to India's Act East Policy and moving through Bangladesh is the way to go according to many scholars rather than directly focusing on Myanmar. Over the last ten years India and Bangladesh have made unprecedented progress in furthering bilateral ties which today covers a wide range of areas including security and defence ties, energy cooperation, trade and investment, greater people-to-people exchange among other things.

DEFENCE COOPERATION - Defence cooperation push between the two neighbours in last few years is evident from the exchange of visits between leaders of two nations as well as the conduct of hard training programmes, joint exercises, humanitarian relief and disaster management (HADR). Prior to Prime Minister Sheikh Hasina's visit in 2017, developments in the arena of defence cooperation took place in the absence of any formal mechanism. For a long time Bangladesh was reluctant to India's security concerns, mainly the safe haven for terrorist groups creating disturbance in the Indian north-east. After 2009 things have begun to change as Dhaka has taken hard stance, arresting top insurgent leaders. Such measures are taken to be crucial for changing defence cooperation scenario.

MoUs have been signed on the framework of defence cooperation, between coast guards of two countries, a line of credit worth $\$ 500$ million for the purchase of defence equipment's, and between

\footnotetext{
7 “China and Bangladesh", www.mfa.gov.cn> Countries in the Region>Bangladesh

${ }^{8}$ Ibid.
} 
Defence colleges of both countries. The most crucial is the finalization of a MoU on the establishment of Coastal Surveillance Radar System in Bangladesh.

The defence services of both countries are now also participating in joint exercises, medical assistance and training programmes. Sampriti, the joint exercise operation between the two armies to counter terrorism, has completed seven rounds. The seventh one took place at the CounterInsurgency and Jungle Warfare School in Vairengte, Mizoram, in November 2017. ${ }^{9}$ Given the growth in the area of defence cooperation experts and analyst suggest that this has to be in the form of institutionalized defence cooperation agreement so that any change in regime can't upset the progress made so far. This initiative has thus far met with objection from different sectors in Bangladesh due to the fact that it could upset China with whom Dhaka shares the one and only defence agreement and such an agreement could be infringement on Bangladesh's strategic autonomy, the Treaty of Peace, Friendship and Cooperation 1972 is used as an example in this regard. ${ }^{10}$ For security analysts in Bangladesh, the rise in defence cooperation with India is indicative of the Bangladesh Army's interest in improving defence ties with India. A section of Bangladeshi security analysts have observed that the importance of maintaining a good relationship with India is now widely understood. This is not to say that the years of mistrust and apprehension can be wished away completely, especially within the army. While India was sceptical about the signing of an MoU instead of an agreement, according to analysts, a comprehensive defence pact may not find easy acceptability but MoUs will create opportunities for expanding defence cooperation in the future.

Countering Terrorism is an important area of defence cooperation between the two countries as both countries have a common history of terrorism in their soil and continue to face evolving security threats. Jammat-ul-Mujahideen's (JMB) operations from Bangladesh since the 2000's pose a threat to both countries and in spite of Dhaka's zero tolerance towards terrorist groups in recent times haven't been able to completely eradicate this menace and the bomb blast in West Bengal's Burdwan in 2014 shows that the cross border problem require a more planned way of dealing with it. Peace and tranquillity in the Bay of Bengal is an important aspect where both countries need to act jointly. The safety and security of maritime trade is what should concern both states which have significant volumes of sea traffic passing through these waters. Anti-piracy operations and disaster relief are exact areas where good progress have been made thus far but more trust and efficient handling is required by coast guards of both states which sees unintended infiltration of shipping boats now and then.

\footnotetext{
9 “'India Bangladesh Joint Military Exercise 'Sampriti' concludes in Mizoram”, Firstpost $17^{\text {th }}$ November 2017.

10 "Defence Pact Detrimental for Bangladesh", available at bdnilitary.com, 27 $7^{\text {th }}$ March 217
} 
TRADE AND CONNECTIVITY - India is the $2^{\text {nd }}$ largest trading partner for Bangladesh but the import export gap is widening day by day. In the last two financial years exports to India increased by $30 \%$ whereas imports from India has increased by $40 \%$. The trade deficit stood at $\$ 7.75$ billion in 2017 18 and is expected to be somewhere close to $\$ 9$ billion at the end of this financial year. New Delhi has removed 47 Bangladeshi products from the negative list of imports in order to allow duty free access of those products. India has also provided duty free access to Bangladesh on all tariff lines except tobacco and alcohol under South Asian Free Trade Agreement (SAFTA) since 2011 but Bangladeshi products haven't been able to take advantage in reducing the bourgeoning trade gap.

India has extended three lines of credits (LOCs) to Bangladesh in the last eight years amounting \$8billion in total. This makes Bangladesh the largest recipient of LOC funds from India. Bangladesh has offered three SEZs for Indian investors, and seeks substantial investment from Indian investors in these three Indian economic zones, namely, Mongla, Bheramara, and Mirsarai to broaden its export base. Total Indian investment proposals in Bangladesh registered with the Bangladesh Investment Development Authority (BIDA) exceeded \$3bn. Indian foreign direct investment (FDI) in Bangladesh reached $\$ 95.41 \mathrm{~m}$ in 2016-17, which was the seventh highest investment in Bangladesh.

India, as it appears, has hitched the wagon to the Bay of Bengal Initiative for Multi-Sectoral Technical and Economic Cooperation (BIMSTEC) as far as the regional groupings are concerned. And the key piece of that BIMSTEC puzzle, is India's key gateways to East Asia is Bangladesh. Two countries recognise that increasing connectivity through air, water, rail, roads offers mutually beneficial opportunity for enhancing economic cooperation between Bangladesh and North Eastern States of India and beyond. The conclusion of Standard Operating Procedures in October 2019 for the use of Chittagong and Mongla ports for movements of goods to and from India, particularly for North East states, would create a win-win situation for both economies. The immense potential of movement of cargo using inland waterways and coastal shipping has opened discussion for operationalization of the Dhulian-Gadagari-Rajashahi-Daulatdia-Aricha route to and fro and include Daudkandi-Sonamura route. The early operationalization Bangladesh Bhutan India Nepal (BBIN) motor vehicles agreement for movements of goods and passengers between the member countries who willing and ready or both the countries are looking to seal a bilateral deal themselves. Bus services are increasing and routes need to expand to ensure cheap 
connectivity. All these measures would do a great deal in preventing illegal movement of people across the borders causing great number of problems. ${ }^{11}$

India have been pushing for a Free Trade Agreement (FTA) or a Comprehensive Economic Partnership Agreement (CEPA) but the thorn in these remains the Teesta River water dispute which requires an amicable solution for better confidence building (River Commissions are necessary in this regard). An asymmetrical trade relations is also a hindrance but any framework like this will be a permanent framework which will help Bangladesh in overall competiveness, elimination of non-tariff barriers, reduce illegal imports from India, will open up specialization of division of labour and more essentially harmonization of standards is likely to benefit Bangladesh as a smaller developing nation.

\section{STRATEGIC OPTIONS FOR BANGLADESH}

After the parliamentary elections in Bangladesh, the Awami League government exudes confidence and with reason. Prime Minister Sheikh Hasina's overwhelming victory in 288 out of 300 parliamentary does place her government with necessary confidence at home but foreign policy issues remain undiminished. Bangladesh's aim to reach a developed country's status by 2040 with the soaring population density is a big challenge at hand and this calls for balancing relations with India and China (who are the main investors in Bangladesh). The geostrategic location of Bangladesh between South and South-East Asia makes matters trickier, as if and when the strategic rivalry between India and China intensifies for dominance in South Asia and Indian Ocean Region (IOR), both countries will double down on their approach to bringing strategically located Bangladesh into their orbit.

India has always been at the centre in Bangladeshi geopolitics while the United States has had leverage. Other regional powers such as China used to be on the periphery. Historically Bangladesh has closer socio-cultural links with India but India's hegemonic posture and coercive tactics haven't gone well with Bangladeshi population at large, mainly with the conservative religious orthodox factions. China's economic engagement with South Asian neighbours, with the exception of its all- weather ally Pakistan, is a recent phenomenon. In this short span of time China has manged to upstage India to become Bangladesh's top trading partner. Imports from China comprises around $40 \%$ of its total imports.

11 "India-Bangladesh Joint Statement during Bangladesh's Prime Minister's official visit to India", available at www.mea.gov.in/bilateral-documents 
Beijing considers China an active member of its Belt and Road Initiative (BRI). It has been participating actively in China's grand project. ${ }^{12}$ Moreover China's offer for making investment of at least \$24 billion In Bangladesh during President Xi Jinping's visit to Dhaka in 2016 has overshadowed India's Line of Credit of \$5 billion. Along with an earlier \$13.6 billion investment in joint ventures, it brings Chinese investment in Bangladesh to a total of $\$ 38$ billion, the most ever pledged to Bangladesh by a single country. As a rapidly developing country Bangladesh requires foreign direct investment (FDI) and is tactfully seizing the opportunity to use both China and India to fill its FDI deficit.

"Maintaining healthy working relations with both India and China is critical for economically and infrastructure weak Bangladesh", writes Irshat Hossain, a research scholar. ${ }^{13}$ China might have an economic edge over India in Bangladesh but India's bond with Bangladesh are far richer and closer and that cannot be wished away so easily. China's ambitious dream of building a deep mesa port in Sonadia remains murky, lacking any notable update amidst rumour that the initiative was blocked by India. In 2017, Bangladeshi navy took delivery of two Chinese submarines which made India clearly uncomfortable and in response India offered training submarine training for the Bangladeshi Navy. Indian Chief of Naval Staff Admiral Lanba visited Dhaka in 2017 and made a significant announcement of Coordinated Patrol (CORPAT) from port city of Chittagong which certainly shows India's desire to have a physical presence in Bangladesh and surrounding waters of Bay of Bengal. This shows India's intent to counter Chinese strategy of surrounding India by the Indian Ocean.

However Bangladesh should be aware of the fact that India-China will be primarily selfserving in their investments. Dhaka needs to use its strategic piston tactfully and remain elusive, without showing any preference of either of the two big brothers. And as things stand it shows that Dhaka has shown considerable dexterity and success so far in this regard. The core of the balancing strategy so far has been Sheikh Hasina's building a fund of mutual trust and goodwill with New Delhi and asserting her country's right to have autonomy in dealing with China and other nations.

Bangladesh's strategy is to incur direct investment from China especially rather than debt financing. "Chinese investment comes in the form of both equity and debt. The infrastructure projects are primarily carried out through debt financing, Dhaka should be interested in equity

\footnotetext{
${ }^{12}$ Ministry of Foreign Affairs of The People's Republic of China, 'China and Bangladesh Hold the $11^{\text {th }}$ Round of Diplomatic Consultation, $11^{\text {th }}$ November 2018', available at https:/www.fmprc.gov.cn/fma_eng

${ }^{13}$ Hossain Irshat, "Bangladesh balances between India and China", available at https://www.eastasiaforum.org/2018
} 
and not debt". ${ }^{14}$ Trade and Investment may not always have the last word in international relations and thus other socio-political events have its say on a country's decision to pursue diplomatic relation with another state. The issue of 1.1 million Rohingya refugees is a mojor problem in front of Dhaka and it requires international help from big powers like India and China to put pressure on Myanmar. India and China both have been silent on these issue thus far due to respective reasons but recently China has shown urge in quietly having talks with Myanmar (also a close ally of China) in two abortive attempts. The enactment of the CAA Act by Indian Parliament are triggering concerns of reverse migration of illegal Muslim immigrants and the dilemma for Bangladesh is an acute one as it doesn't acknowledge illegal migration but perceived notion of atrocities on religious minorities in Bangladesh can upset Dhaka. Thus far though Bangladesh has shown maturity in dealing with the two big brothers India and China.

\section{FUTURE TRENDS FOR INDIA-CHINA RELATIONSHIP}

It may well be possible to manage the Sino-Indian rivalry, but with passing time, India's challenges vis-à-vis China are becoming more intractable. The rivalry though mainly centred on territorial disputes over the un-demarcated Himalayan border has now divulged into many other arenas. Today the rivalry encompasses competition over water sharing, membership in international institutions and specifically on China's foray into India's traditional sphere of influence in the Indian Ocean Region as well as India's increasing interest in the Indo-Pacific and Africa. However, the continued build-up of forces across the border and IOR signify that they have not yet fully made the compromises necessary to avert tensions related to future escalation or conflicts from subsiding.

Smaller states in South Asia like Bangladesh, Myanmar to mention a few, are increasingly playing smart games to hedge between China and India. The ploy seems to be to obtain high levels of economic and military assistance from China and thus forcing India to increase its bid as well. But India lags far behind to China in terms of economic and infrastructure aid. The IOR littoral is fast emerging as China's Ocean too with military bases in Djibouti, one planned in Pakistan and commercial ports in Sri Lanka, Bangladesh, Myanmar, and Maldives. China's BRI though primarily centred on economic and infrastructure development has poised serious geopolitical implications for India, given its unwillingness to join as junior partners and specially the issue concerning Pakistan Occupied Kashmir (POK).

\footnotetext{
14 Interview by Ashan S Mansur to DW, executive director of Dhaka based Policy Research Institute, available at https://www.dw.com/en/is-bangladesh-falling-into-a-chinese-debt-trap
} 
In the given scenario likely options for India has to be the combined use of Soft Balancing and limited Hard Balancing. The latter is the India's attempt to create a triad in the military front and soft balancing would likely mean dealing with issues on the diplomatic front, side by side concentrating on India's ability to influence its partner countries by its wide array of soft powers at hand. 


\section{REFERENCES}

1. S.R, Chakravarty (edited), Foreign Policy of Bangladesh, (Har-Anand publications, 2008), pp. $99-135$

2. Davinder Kumar Madan, Indo-Bangladesh Economic Relations \& SAARC, (Deep and Deep Publications, 1996), pp. 45-65

3. Ashfaqur Rahman, "Rising Together: India, China and Bangladesh", The Daily Star, 28 March 2011

4. Fazle Rashid, "China developing port facilities in Bangladesh, Pakistan, Myanmar", The Financial Express, $17^{\text {th }}$ February 2010

5. Shakil Bin Mushtaq, "The Battle for Bangladesh: India vs China", available at https://www.thediplomat.com/2018

6. Joyeeta Bhatacharjee, "Decoding China Bangladesh Relationship", available at https://www.orfonline.org/expert-speak/41935

7. Samir Kumar Das, “India's Look East Policy: Imagining a New Geography for India's North-East", India Quarterly: A Journal of International Affairs, Vol. 66 No. 4, 2010, pp. 348 349

8. Khawaza Main Uddin, “Analysis - Bangladesh's Acr of Balancing Asian Giant Foes”, available at https://www.aa.com.tr/en/analysis, 13 October 2019 